Jurnal Akuntansi dan Bisnis: Jurnal Program studi Akuntansi, 5 (1) Mei 2019.

ISSN 2443-3071 (Print) ISSN 2503-0337 (Online). DOI: 10.31289/iab.v5i1.2310

JURNAL AKUNTANSI DAN BISNIS

Jurnal Program Studi Akuntansi

Available online http://ojs.uma.ac.id/index.php/jurnalakundanbisnis

\title{
THE DETERMINANT FRAUD PREVENTION OF QUALITY LOCAL GOVERNMENT'S FINANCIAL REPORT
}

\author{
Haryono Umar ${ }^{a^{*}}$, Agustina Indriani ${ }^{b}$, Rahima Br. Purba ${ }^{c}$ \\ ${ }^{a}$ Magister Akuntansi, Pascasarjana, Perbanas Institut \\ ${ }^{b}$ Magister Akuntansi, Pascasarjana, Universitas Trisakti \\ ${ }^{c}$ Akuntansi, Fakultas Sosial \& Sains, Universitas Pembangunan Panca Budi
}

Diterima Maret 2019; Disetujui April 2019; Dipublikasikan Mei 2019

\begin{abstract}
This study empirically aims to analyze the influence of government internal control system and internal monitoring on fraud prevention and its implications on the quality of local financial statements. The data in this study were 89 respondents of local government officials in the city of Bogor and Depok. The methodology using multiple linear regression analysis. The results of the study showed the internal control system positively affects fraud prevention, on the other hand the internal monitoring has no effect on fraud prevention. Fraud prevention has a positive effect on the quality of financial statements. While the government internal control system has a negative effect, the internal monitoring has a positive effect on the quality of local financial report. Government internal control system indirectly affects the quality of local financial statements through fraud prevention, whereas the internal control directly affects the quality of local financial statements through fraud prevention. The result also indicate the fraud prevention has a greater impact on the quality of local financial statements. Internal control system might be minimized fraud and possibility of error. It indicates that fraud prevention support the quality of local financial reporting.
\end{abstract}

Keyword: Government internal control system, internal supervision, fraud prevention, quality of local government financial report

\begin{abstract}
Abstrak
Penelitian ini secara empiris bertujuan untuk menganalisis pengaruh sistem kontrol internal pemerintah dan pemantauan internal terhadap pencegahan penipuan dan implikasinya terhadap kualitas laporan keuangan lokal. Data dalam penelitian ini adalah 89 responden pejabat pemerintah daerah di kota Bogor dan Depok. Metodologi ini menggunakan analisis regresi linier berganda. Hasil penelitian menunjukkan sistem pengendalian internal secara positif mempengaruhi pencegahan penipuan, di sisi lain pemantauan internal tidak berpengaruh pada pencegahan penipuan. Pencegahan penipuan memiliki efek positif pada kualitas laporan keuangan. Sementara sistem kontrol internal pemerintah memiliki efek negatif, pemantauan internal memiliki efek positif pada kualitas laporan keuangan lokal. Sistem kontrol internal pemerintah secara tidak langsung mempengaruhi kualitas laporan keuangan lokal melalui pencegahan penipuan, sedangkan kontrol internal secara langsung mempengaruhi kualitas laporan keuangan lokal melalui pencegahan penipuan. Hasilnya juga menunjukkan pencegahan penipuan memiliki dampak yang lebih besar pada kualitas laporan keuangan lokal. Sistem kontrol internal mungkin meminimalkan penipuan dan kemungkinan kesalahan. Penelitian ini menunjukkan bahwa pencegahan penipuan mendukung kualitas pelaporan keuangan lokal.
\end{abstract}

Kata Kunci: Sistem kontrol internal pemerintah, pengawasan internal, pencegahan penipuan, kualitas laporan keuangan pemerintah daerah

How To Cite: Umar, H. et, al. (2019) The Determinant Fraud Prevention Of Quality Local Government's Financial Report. Jurnal Akuntansi dan Bisnis: Jurnal Program Studi Akuntansi, 5 (1): $41-52$

* email: flamboyan24@gmail.com 


\section{BACKGROUND OF THE STUDY}

Accounting fraud gained much public attention and become familiar of business communities worldwide. Especially, in Indonesia, the fraud has become vicious phenomena from year to year. Financial fraud is a deliberate performance that can result in financial losses. According to Wilopo (2006) accounting fraud is related to corruption in general, which is the common practice is to manipulate record, document removal, and mark-ups are detrimental to the state's finances or economies.

The tendency of fraud is regarded to be a trend for corruption in terminology definition because of the involvement of some elements consisting of misleading facts, rule violations or misuse of trust, and critical fact commission. Many cases of corruption are committed by influential officials who have the power; creating critical (absolute) impacts as a result of their violation (Najahningrum, A. F. 2013).

The problems in this research are indicated some questions such as how does government internal control system influence fraud prevention, what is the influence of internal control on fraud prevention, how does fraud prevention affect the quality of local financial report, how is the effect of government internal control system on the quality of local financial report, how is the influence of internal supervision on the quality of local financial statements, how is the direct and indirect influence of the government's internal control system on the quality of financial statements and how is the direct and indirect influence of internal control over the quality of reports of financial agency of local government. This is interesting to discuss for internal control system literature. Therefore the lack of financial statement reporting indirectly showed the weakness when management knowing that as a fraud indication

In the entity theory (Roberts, 1955), it was stated that the organization is regarded as an independent or business entity, acting on its own behalf and its position is separate from the owner or other party who invests funds in the organization and the economic unity becomes the center of attention or point of view of the accountancy. Reporting entities are a government units consisting of one or more accounting entities which, according to the provisions of the law, are obliged to submit an accountability report in the form of financial statements. Moreover, the accounting entity is a government unit that utilizes the budget or goods and therefore shall be obliged to administer accounting and prepare financial statements to be incorporated in the reporting entity.

In the agency theory, Jensen and Meckling (Michael C. Jensen, 1976) defined that agency relationships are as a contract in which one or more principals hire other parties (agents) to perform some services for their benefit by delegating some decision-making powers to the agents. The problem of agency that arises among executives is that it tends to maximize the self-interest in the preparation or budgeting of the Local Government Budget (APBD), as it has the advantage of information (information asymmetry). For instance, the budgetary slack in APBD is more for the executive's private interests (self interest) rather than for the societies' benefit.

On the other hand, the agency problems arising in the legislature (board members) occur from two different perspectives, namely as the principal over the executive and as agents over the people (voters). The agency problem that emerges from the principal perspective will tend to do a "false contract" with the executive side because it has discretionary power.

In Indonesian context, the government internal control system, according to Regulation No. 60 of 2008 (Peraturan Pemerintah Republik Indonesia, 2008) is defined as "an integrated processes of actions and activities continually undertaken by the leadership and all employees to provide reasonable assurance on the achievement of organizational 
goals through effective and efficient activities, reliability of financial reporting, securing state's assets, and compliance with laws and regulations. ". The components of the government internal control system such as Control Environment, risk assesment, control activities, information and communication and supervision.

Control environment includes enforcement of integrity and ethical values; commitment to competence; conducive leadership; adaptive organizational structure; appropriate authorities delegation and responsibilities; and the preparation and implementation of sound human resources' policies. Risk assessment is identification of entity and analysis of the relevant risks to achieve its objectives, formation of grounds for determining how the risks should be managed. Risk assessment in financial reporting aims to identify, manage, and analyize relevant risks related to financial statements arrangement. Control Activities expained about the availability of procedures, techniques, and control mechanisms that ensure compliance with established directives and proper control in any government agency activities. Regarding information and communication, William and George (2003), argued that information refers to an organization's accounting system consisting of records to identify, organize, classify, analyze, and report organizational transactions. Also, according to Fess (2008), internal supervision monitoring will identify where the weaknesses is found and improve the effectiveness of these controls. Leaders of government agencies are required to conduct regular monitoring so that it can detect when the fraud occurs.

Internal supervision is performed within the judicial environment itself which comprises two types of supervision, namely inherent supervision and functional supervision. Inherent supervision is a series of activities that are continually controlled, performed by direct superior to subordinates in preventive and repressive manner, so that the subordinates are able to perform their tasks effectively and efficiently in accordance with the activity plan and legislation. Supervision is any means that is concerned with the process of careful surveillance, guarding and direction, in order that the objects being supervised can perform as they should be accordingly. Supervision is required to ensure that the implementation of organizational activities remains on the track. Umar 2012 justified through supervision, decision making will receive input for terminating or eliminating errors, deviations, lapses, dissipation, obstacles and injustices; preventing the repetition of errors, deviations, lapses, waste, obstacles and injustices; and will getting a better way in implementing the organization's operations in achieving the vision and performing the mission of the organization.

\section{Fraud Prevention}

Fraud is a legal concept which has broad scope, defined as deception or cheating in the financial field. The Association of Certified Fraud Examiners (ACFE) cited that fraud as unlawful acts committed intentionally (report manipulation or misrepresentation to other parties) perpetrated by persons from within or outside the organization for personal or group's gain that directly or indirectly detrimental to others(Association of Certified Faud Examiners, 2014).

Moreover, Hall (Hall, 2012) defined fraud as a deliberate lie, misrepresentation of company's assets or manipulating financial data for the benefit of the party committing the manipulation. Fraud, according to the standards of the Institute of Internal Auditors (IIA) in Sawyer (Loudder et al., 1992), is an act of deception that includes various irregularities and illegal acts characterized by intentional fraud. fraud is unlawful, fraudulent which means dishonesty. 
Pertaining to corruption, three nonconformities in the fraud triangle are associated with pressures, opportunities, and rationalizations (Murdock, 2008). Furthermore, Wolf and Hermanson (Boyle, Dezoort, \& Hermanson, 2015; Wolfe \& Hermanson, 2003) added these three aspects with one more element, i.e. the power or capability that encourages nonconformities. This fourth aspect, together with three other aspects, is better known as the fraud diamond (Wolfe and Hermanson, 2004). The latest developments of fraud triggered by the enhanced means of corruption lead to public's distrust toward the government, particularly in Indonesia, undermining the integrity of authorities.

\section{Quality of Local Government Financial Report}

Financial statement is the final product of the accounting process which has been performed. It is prepared and arranged in compliance with the principles set forth in Government Regulation No. 71 of 2010 on Governmental Accounting Standards (Indonesia, 2010). Meanwhile, financial reports are arranged by each Regional Work Unit (SKPD) which is then used as the basis for preparing provincial/ district / city government financial report. follows:

Based on literature above, we proposed some hypotheses for further investigation as

H1: The government's internal control system has a positive effect on fraud prevention;

H2: Internal supervision has a positive effect on fraud prevention;

H3: Fraud prevention has a positive effect on the quality of local government's financial statements;

H4: The government's internal control system positively affects the quality of financial statements;

H5: Internal supervision has a positive effect on the quality of local government's financial report.

\section{RESEARCH METHODS}

The research is aimed at performing descriptive evaluation whether there is a relationship or influence among government internal control system, internal supervision, fraud prevention, and quality of financial report of local government. The research is designed using a survey method with associative, descriptive analysis approach.

\section{Operational Definition and Variable Measurement}

For the purpose of this study, there are two independent variables, consisting of government internal control system and internal supervision; there is one dependent variable, i.e. the quality of local government financial statements; and one intervening variable which is fraud prevention. Furthermore, the independent variable of government internal control system (SPIP) is assigned as (X1) and internal supervision as (X2). The dependent variable of the quality of local government financial statements is denoted with (Z). At last, the intervening variable of fraud prevention is denoted with (Y). According to Tuanakotta (2013) fraud prevention starts from the implementation of an effective internal supervision system and dissemination of awareness about the existence of fraud (fraud awareness) and efforts to assess the risk of fraud (fraud risk assessment).

\section{Population, Sample and Methods of Data Collection}


This study used population of local government financial report while the samples were selected using convenience sampling method. The method of convenience sampling is a a way of selection in which preferred sample members are selected or chosen based on convenience factor in obtaining the required data, rather than ones complicating the researcher. The research was conducted at the Secretariat of Local Government, Local Government Financial Agency, and Inspectorate of the city of Depok and Bogor.

\section{Method of Data Collection}

The data used in this study is the primary data derived from respondents' answers to respond the questionnaires. The respondents' occupations are internal supervision. The questionnaire distributed was prepared as a list of written statement to the respondent regarding the influence of internal supervision with the government's internal control system on the quality of local government financial reports through fraud prevention in the administration of City of Bogor. The results of responses were then measured using Likert scale or interval (Hair, Black, Babin, \& Anderson, 2010). The scale consists of five numbers, ranging from 1 to 5 , by which number $1=$ strongly disagree (SD), number $2=$ disagree (D), number $3=$ neutral $(\mathrm{N})$, number $4=$ agree $(A)$, and number $5=$ strongly agree (SA).

\section{Path Analysis}

According to (Hair et al., 2010), path analysis comprises (a) path diagram to describe graphically a structure of relationship between independent variable, intervening variable, and dependent variable. Furthermore, structural equations describe the causal relationship between the variables studied expressed mathematical equations. The structural equation for this research is as follows:

$$
\begin{aligned}
& \text { Fraud }=\mathrm{a}+\mathrm{b} 1_{\mathrm{sPIP}}+\mathrm{b} 2_{\text {int }} \text { Audit }+\mathrm{e} \\
& \text { Quality = } \mathrm{a}+\mathrm{b} 1_{\mathrm{SPIP}}+\mathrm{b} 2_{\text {int }} \text { Audit }+\mathrm{b} 3_{\text {fraud }}+\mathrm{e}
\end{aligned}
$$

Where:

$\begin{array}{ll}\text { Fraud } & =\text { fraud prevention } \\ \text { SPIP } & =\text { government internal control system } \\ \text { Int audit } & =\text { Internal audit } \\ \text { Quality } & =\text { quality of local government financial report } \\ \varepsilon & \quad=\text { degree of error }\end{array}$

\section{RESULT AND DISCUSSION}

Local government officials from both the city of Bogor and Depok were taken as samples of the research. They occupy some positions in the Inspectorate, regional secretariat, and local government financial agency (BKAD) sections. The total number of the samples involved in the study is 89 employees, to whom the questionnaires were distributed. Of the total questionnaires, there were as many as $100 \%$ returned with complete answers. 
Table 1 Descriptive Statistics

\begin{tabular}{cccccc}
\hline & N & Minimum & Maximum & Mean & $\begin{array}{c}\text { Std. } \\
\text { Deviation }\end{array}$ \\
\hline Government internal control & 89 & 1 & 5 & 3.9775 & 0.82541 \\
system (SPIP) & & & & & \\
Internal supervision & 89 & 3 & 5 & 3.9101 & 0.41671 \\
Fraud prevention & 89 & 2 & 5 & 4.0899 & 0.66811 \\
Quality of financial report & 89 & 3 & 5 & 4.2584 & 0.64892 \\
Valid N (listwise) & 89 & & & & \\
\hline
\end{tabular}

Based on Table 1, it can be found the results and analysis of the research. Column $\mathrm{N}$ denotes the number of data used, i.e. 89 respondents. The minimum column presents the least value of each variable. The minimum value of the government internal control system variable is 1 , whereby the internal supervision variable is 3 , the fraud prevention variable is 2 , and financial statement quality variable is 3 ; the maximum column shows the highest value of each variable. The maximum value of the government internal control system variable is 5 , while the internal supervision variable is 5 , the fraud prevention variable is 5 , and the financial statement quality variable is 5 ; the mean column presents the average value of each variable. The average value of the government's internal control system variable is 3.9775, the internal supervision variable is 3.9101, the fraud prevention variable is 4.0899, and the variable of the financial report quality is 4.2584; the std. deviation column denotes the values of standard deviation which are the measure to determine the variation of data distribution. Variable internal control system government is equal to 0.82541 , internal supervision variable is 0.41671 , variable of fraud prevention is 0.66811 ; and variable of quality of financial statements is 0.64892 .

\section{Validity Test Results}

Validity and reliability test was performed to 89 respondents with significance level of 0.05 and $r$ table is equal to 0.2084 . If the value of $r$ arithmetic is greater than that of $r$ table, the statements tested to 89 respondents are considered valid, if otherwise $r$ arithmetic is less than those of $r$ table, the statements are regarded to be invalid. From the results of validity test to 89 respondents on internal government control system variable, internal control, fraud prevention, quality of financial report within 0.05 significance level, it can be concluded that each questionnaire statement is considered valid because $r$ value count $>$ r table.

\section{Reliability Test Results}

Having tested the validity, the reliability was performed to each variable. The test results are described in the following table.

Table 2 Reliability Test Results

\begin{tabular}{ccc}
\hline Variable & Reliability Statistics & \\
Government internal control system & 0.967 & N of Item \\
Internal supervision & 0.884 & 17 \\
Fraud prevention & 0.948 & 30 \\
Quality of financial report & 0.914 & 37 \\
\hline
\end{tabular}

According to the results of the reliability test above, it obtains four outputs of the known variables of each variable which has a value of reliability (Cronbach's Alpha) above 0.60 . Thus, it is concluded that the measuring tool in this study is reliable. 
Using software of SPSS, the normality test result is that the points scattered around the line following the diagonal line; thus, it can be said the regression model has met the normality test and it is normally distributed.

\section{Hypothesis Test Results}

The path analysis in this study used individual and simultaneous test divided into two sub-structures, namely sub-structure 1 and sub-structure 2 . The structural equation of path analysis in this study is as follows:

Table 3 Anova of Sub-Structure 1

\begin{tabular}{|c|c|c|c|c|c|}
\hline \multicolumn{6}{|c|}{ ANOVA $^{b}$} \\
\hline Model & $\begin{array}{l}\text { Sum of } \\
\text { Squares }\end{array}$ & Df & $\begin{array}{l}\text { Mean } \\
\text { Square }\end{array}$ & $\mathrm{F}$ & Sig. \\
\hline 1 Regression & 21693.127 & 2 & 10846.564 & 76.423 & $0.000^{\mathrm{a}}$ \\
\hline Residual & 12205.749 & 86 & 141.927 & & \\
\hline Total & 33898.876 & 88 & & & \\
\hline $\begin{array}{l}\text { Predictors: (constant), SP } \\
\text { Dependent variable: fraud }\end{array}$ & $\begin{array}{l}\text { internal sup } \\
\text { revention }\end{array}$ & sion & & & \\
\hline
\end{tabular}

Sub-structure 1 was analyzed using path analysis with structural equations as previously described. The SPSS program was used to analyze sub-structures 1 which consist of government internal controls, internal supervision, and fraud prevention. Results of sub-structural path 1 analysis as described in the following table. Based on the test results in the table above, it is found that the significance value of 0.000 which is less than 0.05, meaning that the government internal control system (SPIP), internal supervision simultaneously influence the prevention of fraud.

Table 4 Model Summary of Sub-Structure 1

\begin{tabular}{|c|c|c|c|c|c|}
\hline \multicolumn{6}{|c|}{ Model Summaryb } \\
\hline Model & $\mathrm{R}$ & R Square & $\begin{array}{l}\text { Adjusted R } \\
\text { Square }\end{array}$ & $\begin{array}{l}\text { Std. Error of the } \\
\text { Estimate }\end{array}$ & Durbin-Watson \\
\hline & $0.800^{\mathrm{a}}$ & 0.64 & 0.632 & 11.913 & 1.869 \\
\hline \multicolumn{6}{|c|}{$\begin{array}{l}\text { a. Predictors: (constant), internal supervision, government internal control system. } \\
\text { b. Dependent Variable: fraud prevention }\end{array}$} \\
\hline
\end{tabular}

The value of the influence of government internal control system and internal supervision on fraud prevention is derived from adjusted $\mathrm{R}^{2}$, i.e. 0.632 or $63.2 \%$. Thus, intuitively, the value of influence of other factors affecting the fraud prevention outside this research is $100 \%-63.2 \%=36.8 \%$.

Table 5 Coefficients of Sub-Structure 1

\begin{tabular}{ccrrr}
\hline & & & \multicolumn{2}{c}{ Unstandardized } \\
& & \multicolumn{2}{c}{ Coefficients } & Sig. \\
& & B & Std. Error & \\
\hline 1 & (Constant) & 58.606 & 13.095 & 0.000 \\
SPIP & 1.187 & 0.097 & 0.000 \\
& Internal supervision & 0.124 & 0.098 & 0.209 \\
\multicolumn{2}{c}{ a. Dependent Variable: fraud prevention } \\
\hline
\end{tabular}

The structural equation of substructure 1 is as follows:

$$
\text { Fraud }=58.606+1.187 \times 1+0.124 \times 2
$$




\section{The influence of government internal control system on fraud prevention ( $X_{1} \rightarrow Y$ )}

Based on the test results explained above, it is found that the government internal control System (SPIP) variables show the value of $\beta=1.187$ while the significance value of 0.000 is less than 0.05 ; so that Hypothesis 1 (one) is accepted. It means that the government internal control system (SPIP) has a positive effect on fraud prevention. The activities of fraud prevention carried out in terms of policies, systems and procedures establishment can provide reasonable assurance in achieving organizational goals through internal control. Therefore, when the internal control of a business entity is poor, the entity will be likely to experience errors and fraud. On the cocntrary, if its internal control is robust, it will less tend to experience error and fraud. This study supports the findings of Taufik (2011), Rendika (2013), Armando (2013), Hendriani (2013), Komang et al. (2014), which stated that the government internal control system has a positive effect on fraud prevention.

\section{Influence of Internal Control on Fraud Prevention $(X 2 \rightarrow Y)$}

Referring to the test results, it is found that internal control variables show the value of $\beta=0.124$ and its significance value of 0.209 which is greater than 0.05 . As a consequence, Hypothesis 2 is rejected accordingly, by which the internal control variable does not affect the prevention of fraud. This might occur since the management under internal supervision that issue an internal control report does not mend the weaknesses existing in the control resulting in fraud occurrence. However, this finding is not in accordance with the results of Taufik's research (2011), Rendika (2013), Yuliarta (2013), Sari (2012), Umar (Umar \& Nasution, n.d.) stating that internal controls have a significantly positive impact on fraud prevention.

\section{Sub-structure 2 Testing}

Table 6 Anova of Sub-Structure 2

ANOVA $^{b}$

\begin{tabular}{|c|c|c|c|c|c|c|}
\hline & Model & $\begin{array}{c}\text { Sum of } \\
\text { Squares }\end{array}$ & Df & $\begin{array}{c}\text { Mean } \\
\text { Square }\end{array}$ & $\mathrm{F}$ & Sig. \\
\hline \multirow[t]{3}{*}{1} & Regression & 12155.832 & 3 & 4051.944 & 249.806 & $0.000^{\mathrm{a}}$ \\
\hline & Residual & 1378.730 & 85 & 16.220 & & \\
\hline & Total & 13534.562 & 88 & & & \\
\hline
\end{tabular}

a. Predictors: (constant), fraud prevention, internal supervision (SPIP)

b. Dependent variable: quality of financial report

Based on the test results above, it is obvious that the significance value of 0.000 is less than 0.05 , meaning that the prevention of fraud, government internal control system (SPIP), and internal supervision simultaneously affect the quality of financial statements.

Table 7 Model Summary of Sub-Structure 2

\begin{tabular}{|c|c|c|c|c|c|}
\hline \multicolumn{6}{|c|}{ Model Summary ${ }^{b}$} \\
\hline Model & $\mathrm{R}$ & R Square & $\begin{array}{l}\text { Adjusted R } \\
\text { Square }\end{array}$ & $\begin{array}{l}\text { Std. Error of the } \\
\text { Estimate }\end{array}$ & $\begin{array}{l}\text { Durbin- } \\
\text { Watson }\end{array}$ \\
\hline 1 & $0.948^{a}$ & 0.898 & 0.895 & 4.027 & 1.919 \\
\hline
\end{tabular}

a. Predictors: (constant), fraud prevention, internal supervision, SPIP

b. Dependent variable: quality of financial report 
The value of influence of fraud prevention on the quality of financial statements can be observed through the adjusted R2 $=0.895=89.5 \%$ while the degree of influence of other factors on the quality of financial statements outside this study is $100 \%-89.5 \%=$ $10.5 \%$.

Table 8 Coefficients of Sub-Structure

\begin{tabular}{rcrrrr}
\hline & & \multicolumn{2}{l}{ Unstandardized } & \\
& Model & \multicolumn{2}{c}{ Coefficients } & Sig. & \multicolumn{1}{c}{ T } \\
\hline \multirow{2}{*}{1} & (Constant) & 0.262 & 4.915 & 0.958 & 0.053 \\
& SPIP & -0.592 & 0.054 & 0.000 & -10.912 \\
& Internal supervision & 0.137 & 0.033 & 0.000 & 4.103 \\
& Fraud prevention & 0.842 & 0.036 & 0.000 & 23.098 \\
\hline
\end{tabular}

a. Dependent variable: quality of financial report

Based on Table 8 above, the regression model derived from the research results is mathematically formulated as follows:

$$
\text { Quality }=0.262+(-0.592) \text { SPIP + 0.137Int Audit }+0.842 \text { Fraud }
$$

Based on the above table it can be obtained testing hypothesis as follows:

\section{Influence of Fraud Prevention on Quality of Local Government Financial Report (Y $\rightarrow \mathrm{Z}$ )}

Based on the above test results, it is found that fraud prevention variables show $\beta=$ 0.842 and significance value 0.000 less than 0.05 ; as a consequence, Hypothesis 3 is accepted, indicating that fraud prevention positively affect the quality of local government financial statements. Auditors play salient roles in preventing and minimizing fraud, detecting an attempt to fraud. To overcome the issues associated with fraud, several attempts can be performed, such as increasing prevention activities and investigation audit. In addition, this study conforms to the results of the study of Adeyemi, et al. (2012), Bastian (2010) which stated that fraud prevention affects the quality of financial statements.

\section{Influence of Government Internal Control System (SPIP) on Quality of Local Government Financial Report}

Based on the results above, it is found out that the variable of internal government control system shows the value of $\beta=-0.592$, significance $=0.000$ which is less than 0.05 . It indicates that Hypothesis 4 is to be rejected which means the government internal control system negatively affects the quality of local government financial report. The role of auditors in fraud prevention is to understand fraud elements and its types that may occur in the government. Furthermore, this study supports Adeyemi, et al. (2012), Bastian (2010) which stated that fraud prevention affects the quality of financial statements.

\section{Influence of Internal Supervision on Quality of Local Government Financial Report}

Referring to the results, it can be observed that the fraud prevention variables show $\beta=0.137$, significance value of 0.000 which is less than 0.05 ; thus, Hypothesis 5 should be accepted or, in other words, internal supervision positively affect the quality of local financial statements through fraud prevention. This is the case since the management in internal supervision issuing an internal report of internal control does not perform corrective actions addressed to the drawbacks existing in internal control; hence, it results in poor quality of local government financial statements. More commonly, management takes less attention to the internal audit report, as such; there is no corrective action for 
improvement of financial report quality. Furthermore, this research's finding is in agreement with that of Astuti (2016) stating that internal control has positive effect on quality of local government financial report.

\section{Intervening Testing}

To investigate the direct and indirect influence, the path analysis results as shown in Figure 2 can be used for a reference.

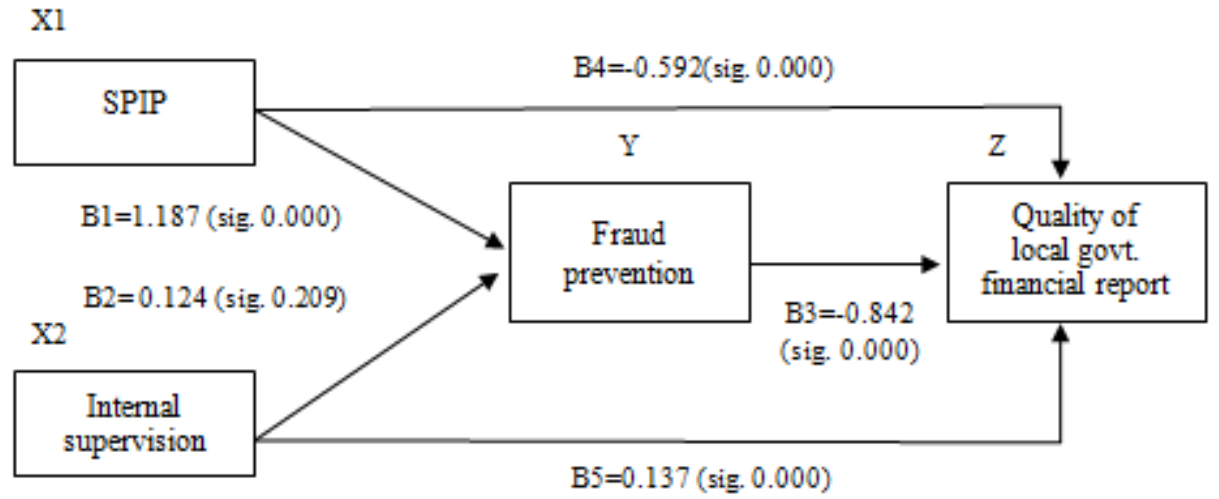

Referring to Figure 2, to investigate the indirect effect of SPIP and internal supervision variable on the quality of financial report variable, calculation was performed with Sobel Test approach. The Sobel Test results are obtained as shown in the following table.

Table 9. Matrix of Direct and Indirect Influence

\begin{tabular}{|c|c|c|c|c|c|c|c|c|}
\hline \multirow{3}{*}{$\begin{array}{c}\text { Types of } \\
\text { influence } \\
\text { Independent } \\
\text { variable }\end{array}$} & \multicolumn{6}{|c|}{ Indirect } & \multicolumn{2}{|c|}{ Direct } \\
\hline & \multicolumn{2}{|c|}{ Path $\mathrm{X} \rightarrow \mathrm{Y}$} & \multicolumn{2}{|c|}{ Path $\mathrm{Y} \rightarrow \mathrm{Z}$} & \multicolumn{2}{|c|}{ Sobel Test } & \multirow{2}{*}{$T$} & \multirow{2}{*}{ Sig. } \\
\hline & $B$ & Std Error & $B$ & Std Error & $t$ & Sig. & & \\
\hline SPIP & 1.187 & 0.097 & & & 10.842 & 0.000 & -10.912 & 0.000 \\
\hline Internal & 0.124 & 0.098 & & & 1.263 & 0.103 & 4.103 & 0.000 \\
\hline supervision & & & 0.842 & 0.036 & & & & \\
\hline
\end{tabular}

Source: data processing (Sobel calculator, 2017)

Results of Sobel test path analysis are described in the following passages.

\section{Direct and indirect effect of government internal control system on the quality of local government financial report}

The result of the sobel test shows that the value of $\mathrm{t}$ arithmetic line $\mathrm{X} 1 \rightarrow \mathrm{Y} \rightarrow \mathrm{Z}$ is 10.842 or less than that of $t$ table $(10,842<1,986)$ with 0,000 significance level. This result indicates that SPIP has indirectly positive influence on the quality of local government financial report (SPIP) to the fraud prevention, eventually on the quality of local government financial statements. The magnitude of the direct effect is -0.592 while that of of indirect one is $1.187 \times 0.842=0.999$. Since the magnitude of the direct effect is less than that of the indirect effect $(-0.592<0.999)$, it can be concluded that the actual effect is the indirect effect.

In preparing local government financial statements, it has to go through a sequence of processes and stages which are regulated in the government internal control system in order to prevent the occurrence of fraud. The quality of financial statements is greatly influenced by the quality of the local government's internal control system. Financial reports in the public sector institutions play an important role in preventing fraud. The 
greater demand for the quality of financial statements in the fraud prevention will lead to improved government internal control system. Thus, it can be said that the internal control system of the government has an indirect effect on the quality of local government financial statements through fraud prevention.

\section{Direct and indirect influence of internal control on the quality of local government financial statements}

Based on the test, the value of $t$ arithmetic is 1.263 or less than that of table 11.263 $<1.986$ ) at significance level of 0.103 . This result indicates that internal control does not indirectly affect the quality of regional financial report, whether it is from internal control, fraud prevention, nor the regional financial statements. The value of direct influence is 0.137 and that of indirect effect is $0.124 \times 0.098=0.012$. Since the value of direct effect is greater than the indirect one $(0.137>0.012)$, it can be inferred that the actual effect is a direct effect. One of the internal control components is supervisory activities dealing with periodic or continual assessment of the performance quality or internal control performance. One of the functions of supervision is to perform immediate corrective actions, at any time, when it is found the existence of deviation, fraud, misconduct, and resources dissipation. Hence, the financial information which has been provided becomes valid and relevant. In other words, it can be said that internal control of the government directly affects the quality of local government financial statements through fraud prevention.

\section{CONCLUSION}

Based on the results of the analysis and discussions section we argue some conclusions; first, government internal control system (SPIP) has a positive effect on fraud prevention. The second, internal supervision has no effect on fraud prevention. However, the research results are not in line with Umar (Umar \& Nasution, n.d.) the fraud prevention has a positive effect on the quality of local government financial statements. Government's internal control system negatively affects the quality of local government financial reports. Internal supervision has a positive effect on the quality of local government financial report. Government's internal control system has an indirect effect on the quality of local government financial report through the fraud prevention, and internal supervision directly affects the quality of local government financial reports through fraud prevention.

\section{REFERENCE}

Association of Certified Faud Examiners. (2014). Report To the Nations on Occupational Fraud and Abuse. Global Fraud Study (Vol. 15). https://doi.org/http://dx.doi.org/10.2139/ssrn.2222608

Boyle, D. M., Dezoort, F. T., \& Hermanson, D. R. (2015). J . Account . Public Policy The effect of alternative fraud model use on auditors ' fraud risk judgments. JOURNAL OF ACCOUNTING AND PUBLIC POLICY. https://doi.org/10.1016/j.jaccpubpol.2015.05.006

Hair, J. F., Black, W. C., Babin, B. J., \& Anderson, R. E. (2010). Multivariate Data Analysis. Vectors. https://doi.org/10.1016/j.ijpharm.2011.02.019

Hall, J. A. (2012). Accounting Information Systems. IEEE Transactions on Information Theory (Vol. 58). Retrieved from http://ieeexplore.ieee.org/lpdocs/epic03/wrapper.htm?arnumber=6071007

Indonesia, R. Peraturan Pemerintah Republik Indonesia No. 71 Tahun 2010 Tentang Standar Akuntansi Pemerintahan (2010).

Loudder, M. L., Khurana, I. K., Sawyers, R. B., Cordery, C., Johnson, C., Lowe, J., \& Wunderle, R. (1992). The Information-Content of Audit Qualifications. Auditing-a Journal of Practice \& Theory, 11(1), 69-82.

Michael C. Jensen, M. W. H. (1976). Theory Of The Firm : Managerial Behavior, Agency Cost And Ownership Structure. Journal of Financial Economics, 3, 305-360.

Najahningrum, A. F. (2013). Faktor-faktor yang Mempengaruhi Kecenderungan Kecurangan (Fraud): Persepsi Pegawai Dinas Provinsi DIY (Doctoral dissertation, Universitas Negeri Semarang). 
Peraturan Pemerintah Republik Indonesia. Peraturan Pemerintah republik Indonesia No. 60 Tahun 2008 Tentang Sistem Pengendalian Intern Pemerintah (2008). https://doi.org/10.1017/CB09781107415324.004

Roberts, A. T. (1955). The Proprietary Theory and the Entity Theory of Corporate Enterprise .

Umar, H. (2011). Government Financial Management Strategy for Preventing Corruption in Indonesia. The South East Asian Journal of Management, 5(2), 19-36.

Umar, H. (2012). Pengawasan Untuk Pemberantasan Korupsi. Jurnal Akuntansi \& Auditing.

Umar, H., \& Nasution, M. I. (n.d.). Saudi Journal of Business and Management Studies ( SJBMS ) The Influence of the Government Internal Control System and Internal Audit on Corruption Prevention Mediated By Implementation of Actuals-Based Accounting, 6663. https://doi.org/10.21276/sjbms.2018.3.3.16

Umar, H. (2016). Corruption The Devil, Cetakan Pertama, Penerbit Universitas Trisakti, Jakarta.

Wilopo. (2006). Analisis Faktor-faktor yang Berpengaruh Terhadap Kecenderungan Kecurangan Akuntansi: Studi pada Perusahaan Publik dan Badan Usaha Milik Negara di Indonesia. Jurnal Riset Dan Akuntansi Indonesia, 9(3), 346-366.

Wolfe, B. D. T., \& Hermanson, D. R. (2003). The Fraud Diamond : Considering the Four Elements of Fraud, 2. 